\title{
INVESTMENTS OF THE EBRD IN THE INFRASTRUCTURE SECTOR OF SERBIA
}

\author{
KOSUTIC Aleksandar ${ }^{1}$, HADZIC Miroljub ${ }^{2}$ \\ 1 Interkomerc $A D$, Belgrade (SERBIA) \\ 2 Singidunum University, (SERBIA) \\ E-mail: kosuticaleksandar@yahoo.com
}

\begin{abstract}
In the world of infrastructure investments, international financing represents a key determinant and the basis for a larger and more successful development of small economies in Europe and the world. There is a very important role played by international financial institutions that provide financial investment and incentives without which the progress of small and stunted economies, potentially prosperous, would not be possible. Consequently, we will try to further explore the characteristics, significance and structure of EBRD's investment in the infrastructure sector of the Republic of Serbia, thus making a review of this sector of the Republic of Serbia.
\end{abstract}

Keywords: EBRD, investments, infrastructure sector, economy, bank

JEL: G20

UDC: 339.727.22:338.49(497.11)

COBISS.SR-ID 277951756 


\section{INTRODUCTION}

The subject of the research is investment in the infrastructure by the European Bank for Reconstruction and Development (EBRD) during the global economic crisis. The European Bank for Reconstruction and Development invests in the projects in EU countries and partner countries. The sector of particular interest for investments is the infrastructure sector. In the countries of the European Union, governments adopt regulations that are focused on the development of the infrastructure sector. Infrastructure sectors must be seen as the main drivers of innovation, employment, and also social and local integration in Europe. It is therefore considered that it is very important to create the best possible environment for the needs of growth and development of this sector in the function of faster sustainable growth and the development of national economies.

The scientific goal of the research is the scientific description of the stimulation of the infrastructure sector by the European Bank for Reconstruction and Development in the conditions of the global economic crisis. The results of the research should point to the role that the European Bank has in the development of our country, with particular reference to the infrastructure sector.

The social goal is to meet the practical needs, ie. that the basic research findings will be in the function of improving the cooperation of our country with the EBRD and improving the performance of its investments, in order to accelerate growth and development of the Serbian economy.

General hypothesis:

- The European Bank for Reconstruction and Development approves those investment projects in the infrastructure sector that contribute to improving the infrastructure conditions in the Republic of Serbia.

Special hypotheses:

- European Bank for Reconstruction and Development applies a situational approach to the governance; the approval of investment projects depends on a particular situation, political, economic and infrastructural factors and aspects.

- European Bank for Reconstruction and Development has assumed an important role in lending to the economy, especially in the sphere of the infrastructure sector.

Individual hypothesis:

- European Bank for Reconstruction and Development was one of the leading investors in the infrastructure sector in Serbia during the transition period.

- There is still a great need for the financing of infrastructure projects in Serbia,

Theoretical and methodological approach to research is dialectical. The basic methods applied were analytical methods, basic synthetic methods, and general scientific methods. From the analytical basic methods, we applied the method of analysis, method of abstraction, method of specialization and deduction method. The synthetic basic methods we have used in the research are: synthesis, concretization, generalization and induction. We applied the method of data collection and content analysis and factor analysis. 
Starting from the set hypotheses and goals of the research, the corresponding structure of work also emerged.

The first part deals with the EBRD's investment in the infrastructure sector, the other part relates to specific projects of the infrastructure sector, followed by a conclusion and a literature review in the end.

\section{THE IMPORTANCE OF THE EBRD'S INVESTMENT IN THE INFRASTRUCTURE PROJECTS}

The EBRD has tied a lot of its investments in the Republic of Serbia to the improvement of the infrastructure modernization throughout the whole territory of Serbia. So far, 29 large projects have been implemented, 27 of which are of public importance with 1,291 million Euros invested. These projects are funded in line with the main European goals set by the European Commission, the Council of Europe and other EU supervisory authorities in the field of infrastructure. It should be emphasized that, in line with the European guidelines for economic prosperity for the region of the Western Balkans, the main task is to ensure a stable economy and development. One of the basic preconditions for such development is the realization of infrastructure projects. The activity of the EBRD in the territory of the present Republic of Serbia has been going on for nearly 20 years. The Action plan for the infrastructure projects was created for the first time in 2003, but for the past 10 years there was a noticeable momentum in infrastructure investments. Namely, the investment in infrastructure was one of the priorities for the EBRD's operations in the Republic of Serbia. Of course, as in other countries of the region and beyond, there are still many problems regarding to the bureaucratic obstacles, procedures, lack of adequate documentation and the lack of more serious additional sources for co-financiers in the projects. What is often a problem in the business practice is not having an idea and activities for business investment in projects and non-withdrawal of funds. Very often in the business environment, the problem of non-withdrawal of funds by the EBRD is considered a not-so-wise decision, as it is usually assumed that the co-perpetrator of the project doesn't have all the fulfilled technical and legal conditions for the good execution of the project, which are solely his responsibility. These cases are not frequent but they still exist, especially in the area of energetic efficiency. In the structure of the EBRD's total investments, investments in the infrastructure projects have a share of $37.7 \%$. By investing in the improvement of infrastructure, the EBRD is improving the economic climate, providing better general business conditions, which creates a basis for improving the living standards of citizens, and thus contributes to the faster and more quality development of our country.

At the gathering of countries of the Western Balkans in Sofia, held on May 17, 2018, attended by EBRD President Suma Chacabrati, was emphasized the importance of engaging of the EBRD in the area of infrastructure, and it was noted that one of the priorities of the EBRD will be the development of an infrastructure that stimulates economic growth in the region, and link countries closer to each other and with Europe.

Without the EBRD's support in the modernization of the infrastructure sector, the Serbian economy would not have all the necessary infrastructural conditions at a satisfactory level, and without this kind of assistance, its economy would have a slower development than the one potentially possible. The investment effect of the EBRD is primarily seen in better traffic connections, which are linked to numerous and extensive investments in the road network, in the rehabilitation of roads such as: Corridor X, the bridge over Ada Ciganlija, reconstruction of 
the Belgrade-GSP bus fleet, then the reconstruction project of the Gazela bridge, rehabilitation of the Corridor X railroad, reconstruction of the Belgrade-Novi Sad highway, reconstruction of the infrastructure of the city of Kragujevac, reconstruction of the infrastructure of the city of Subotica, etc. EBRD investments were also focused on environment preservation projects such as: the project for remediation of Belgrade Solid Waste PPP, the water supply and sewage repair project, JKP Belgrade water system - Makiš, Duboko - solid waste remediation project, Užice and Čačak, Dolovo Veteropark project, Kovačica - wind farm, one of the leading goals of the EUROPEAN UNION, as well as its EBRD instrument, is the preservation of the environment. We must note that European Union has committed itself to the environment protection consent, signed in the Kyoto city of Japan, to exclusively base its investments on projects that are not harmful to the environment and preserving all natural resources. Therefore, in the last 10 years, emphasis is placed on projects that are in the domain of construction and processing of all types of waste, the creation of a plan for the recovery of waste of all major environmental pollutants, and their disposal. In particular, we emphasize that this is not only one of the goals, but also a condition for the countries of pre-accession membership to fulfill, in order to be able to enter the final phase of the final accession to the European Union. Not a single infrastructure project, in which the EBRD took part, will endanger the environmental aspects of the project. We will now look at a chart in which you can see the areas of the environment in which the European Union invested in the previous period in our country.

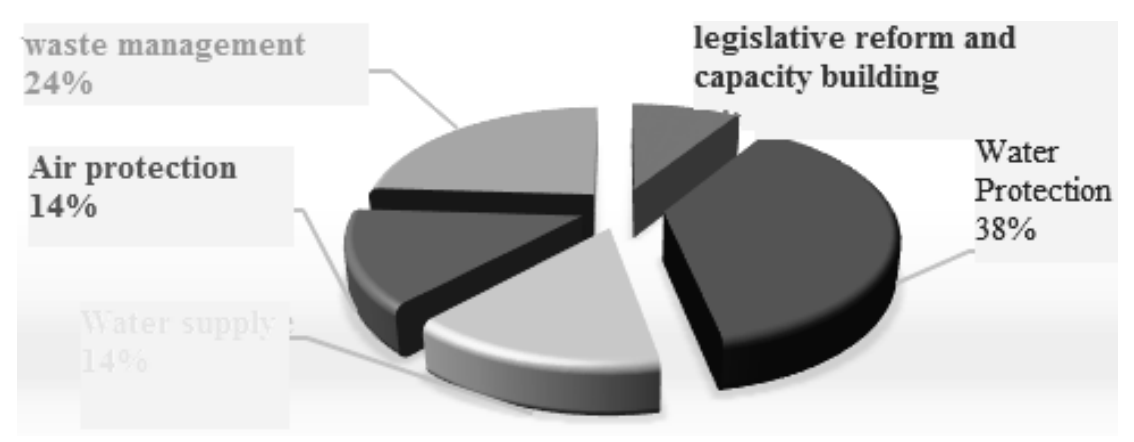

Figure 1. EU's aid to the environment sector

Total aid to the environment protection from 2000 to 2013 is about 700 million euros. The aid that is in progress amounts to over 113 million euros, while planned future aid should amount to 73 million euros.

A number of projects have been implemented through the "EU PROGRESS-European Partnership with Municipalities Program", the so-called European program of partnership with local communities, as well as other programs that the European Union has. The aim of this program is to greatly contribute to the improvement and increase of the degree of stability, and socio-ecological development as the primary factor in the south and southwestern Serbia. These include projects in infrastructure, and investment in the environment. Many partners of this program are the Delegation of the European Union in Serbia, the Government of the Swiss State, and the Swiss Office for Development and Cooperation in the Republic of Serbia, the Ministry of the Republic of Serbia, and the United Nations Office in the Republic of Serbia. Of course, this type of program is very important, and donations, loans, investments in the infrastructure, as well as in all other branches, are very important decisions, but it should be emphasized that $80 \%$ of these investments are going through the EBRD - the European Bank for Reconstruction and Development, EIB - European Investment Bank, EIF - European Investment Fund. Mostly they are co-financed projects with other project funders. 


\section{EXAMPLES OF PROJECTS IN THE INFRASTRUCTURE, FINANCED BY EBRD}

\section{Duboko Solid Waste project, Duboko waste remediation (Regional sanitary Landfill)}

The project, initiated in 2006, aims to build a regional landfill site that will serve for nine municipalities: Čačak, Užice, Bajina Bašta, Požega, Arilje, Čajetina, Kosjerić, Lučani and Ivanjica. In addition, the project involves the construction of two lines that would be used for the separation of recyclable materials, as well as the administration and laboratory building, a facility for washing and disinfecting vehicles, a substation, communication areas and infrastructure (internal roads) and zone protection around the site.

The project further includes 3 mobile stations, the transport and closure of existing landfills. It is expected that the closure of existing landfills and the purification and rehabilitation of this area will be financed through the EAR funds and the Eco Fund of the Government of Serbia.

The project was signed in 2008 when the Duboko company bank provided a loan of 5 million euros for the construction of a landfill site in the region. The financing of the bank was complemented by EU funding, a grant provided by the Government of Serbia and a contribution of nine municipalities, a total of 12.1 million euros. Due to unexpected landslides that occurred during the construction phase, the initial financing plan increased, so the total estimated project cost was 19.1 million euros. This financial increase was partly covered with 2.4 million euros as support from the Swedish agency for international development cooperation ("Sida").

In order to further stabilize and expand the capacity of the landfill, Sida has funded further technical assistance for the preparation of detailed technical studies and designs for stabilization and extended landfill capacity. According to the project, additional investments for the stabilization and expansion of landfill capacities are estimated at 4.5 million euros. Sida has made another support that will be channeled through the EBRD under the EBRD SWME Fund in an approximate amount of 2.5 million euros for capital and technical assistance. The Serbian government has indicated that it is ready to provide an amount of 2 million euros to finance the remaining amount required for completion of landfill works. These works include stabilization work and landfill design changes to ensure lasting stability with increased landfill capacity. Potential environmental and social impacts associated with changes in design and increased capacity is assessed through the Environmental and Social Impact Assessment (ESIA) and appropriate mitigation measures.

\begin{tabular}{|l|c|}
\hline \multicolumn{1}{|c|}{ The project will be financed by: } & The financial plan for building the "Duboko" project is: \\
\hline $\begin{array}{l}\text { 1. Fund for the protection of environment of } \\
\text { the Republic of Serbia }\end{array}$ & Eco Fund 1.527.060 $€$ \\
\hline $\begin{array}{l}\text { 2. Nine (9) participating municipalities } \\
\text { 3. European Agency for Reconstruction } \\
\text { (EAR) via donation }\end{array}$ & All nine municipalities 2.533.111 $€$ \\
\hline $\begin{array}{l}\text { 4. European Bank for Reconstruction and } \\
\text { Development (EBRD) via loan }\end{array}$ & EAR 2.969.822 $€$ \\
\hline TOTAL (€) $\quad$ EBRD 5.179.161 $€$ \\
\hline
\end{tabular}

Figure 2: Project ,, Duboko,, 
The waste Management Company Duboko is a company founded for the construction and management of a regional solid waste landfill for nine municipalities. The company is majority owned and controlled by the municipalities of Čačak and Užice.

Municipalities of Užice, Bajina Bašta, Požega, Arilje, Čajetina, Kosjerić, Lučani and Ivanjica in 2005 have concluded the Agreement on the establishment, construction and use of the regional sanitary landfill "Duboko", where they, as founders, regulated mutual rights and obligations related to the establishment, construction, financing and exploitation of the Regional sanitary landfill Duboko.

Table 1. Ownership structure of the "Duboko" company

\begin{tabular}{clc}
\hline Number & Founder cities and municipalities & Percentage of participation in financing \\
\hline 1 & City of $U$ Žice & $\mathbf{2 3 . 9 1 \%}$ \\
\hline 2 & City of Čačak & $\mathbf{2 6 . 8 8 \%}$ \\
\hline 3 & Ivanjica Municipality & $\mathbf{1 0 . 2 0 \%}$ \\
\hline 4 & Požega Municipality & $\mathbf{9 . 3 0 \%}$ \\
\hline 5 & Bajina Bašta Municipality & $\mathbf{8 . 3 9 \%}$ \\
\hline 6 & Lučani Municipality & $\mathbf{7 . 0 9 \%}$ \\
\hline 7 & Arilje Municipality & $\mathbf{5 . 7 0 \%}$ \\
\hline 8 & Cajetina Municipality & $\mathbf{4 . 5 0 \%}$ \\
\hline 9 & Kosjerić Municipality & $4.03 \%$ \\
\hline \multicolumn{2}{r}{ Total } \\
\hline
\end{tabular}

Surce: www.duboko.rs

EBRD Project Financing.

A loan of up to 5 million euros for Duboko is secured by an agreement on municipal support by the cities of Čačak and Užice, as well as other municipalities. During 2013, it became apparent that the stabilization at the existing site of the Duboko landfill will not be sufficient to protect the long term "shelf life" of the landfill. In accordance with the priorities of the Ministry of Agriculture and Environmental Protection, Sida has provided great support for the provision of permanent landfill stability and its expansion for the second allocation of landfills in the amount of 1.5 to 2 million euros. In connection with this, Sida hired a technical adviser in the summer of 2014 to consider the various options for preserving the operation of the Duboko landfill in the long-term perspective.

The financial plan of this project consisted of the following: ${ }^{1}$

In the first phase, there is a basis for implementing this first initial phase of the project. The regional sanitary landfill Duboko is now one of the largest, if not the most modern infrastructure projects for the waste treatment and environmental protection that has been successfully implemented, and which greatly reflects all the necessity for further investments and investments of this type, the project that connected the 9 municipalities enabled the processing of the total non-

\footnotetext{
${ }^{1}$ A draft of EIA 2007 - Volume I 163-1/07/Duboko, and non-technical* summary, May 24 ${ }^{\text {th }}$ 2007. MOL, Belgrade-11
} 
hazardous waste from these 9 municipalities. This project progresses from year to year and JKP DUBOKO is one of the best investments in this part of the Western Balkans Region.

In order to support this thesis, we will explore the possible cost-effectiveness of the project itself, namely, the return on the capital of the project itself:

\section{JKP Duboko Užice}

Calculation: (AOP 1064: S. NET GAIN or AOP 1065: T. NET LOSS) / AOP 0401: CAPITAL

Table 2. Return on equity rate (ROE)

\begin{tabular}{ccccc}
\hline & Net gain & Net loss & Capital & ROE \\
\hline $\mathbf{2 0 1 4}$ & 82417000 & & 760744000 & $10.83 \%$ \\
\hline $\mathbf{2 0 1 5}$ & 94207000 & & 726667000 & $12.96 \%$ \\
\hline $\mathbf{2 0 1 6}$ & 105513000 & & 865136000 & $12.19 \%$ \\
\hline $\mathbf{2 0 1 7}$ & & 18637000 & 789006000 & $-2.36 \%$ \\
\hline
\end{tabular}

Source : Knežević et al. (2017)

Calculation: (AOP 1030: V. BUSINESS PROFIT or AOP 1031: G. BUSINESS LOSS) / AOP 0071: D. TOTAL ASSETS

Table 3. Return on assets rate (ROA)

\begin{tabular}{ccccc}
\hline & Business profit & Business loss & Total assets & ROA \\
\hline $\mathbf{2 0 1 4}$ & 168258000 & & 1519177000 & $11.07 \%$ \\
\hline $\mathbf{2 0 1 5}$ & 110779000 & & 1474718000 & $7.51 \%$ \\
\hline $\mathbf{2 0 1 6}$ & 118283000 & & 1443346000 & $8.19 \%$ \\
\hline $\mathbf{2 0 1 7}$ & & 45260000 & 1489358000 & $-3.03 \%$ \\
\hline
\end{tabular}

Source : Knežević et al. (2017)

In the future, according to the projection, the company will generate an average of $0.19 \%$ of return on capital, which would allocate her alongside similar companies in Central and Eastern Europe, so we can conclude that the investments of all participants in this project, including the EBRD, are profitable.

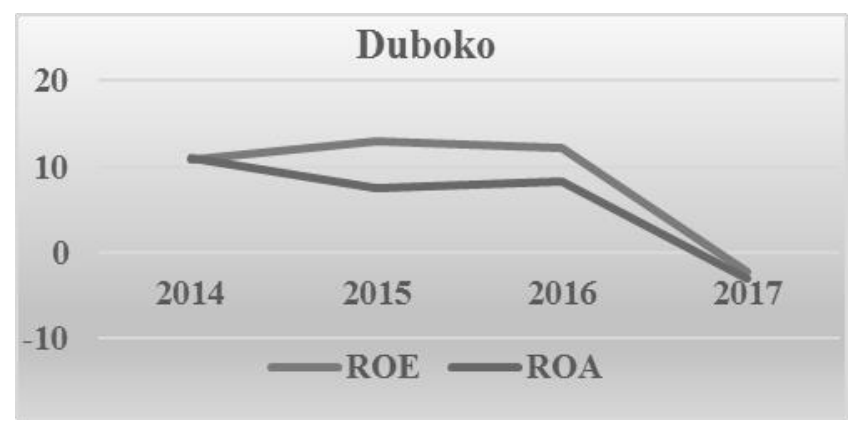

Figure 3. Return on assets rate 


\section{Belgrade Public Transport and Traffic Infrastructure project}

The project belongs to one of the larger EBRD's investments, and is very important from the aspect of improving the quality of life and work of the citizens of Belgrade. The total loan amount is $\mathbf{5 7}$ million euros. The purpose of the loan is the following:

- Adaptation and modernization of tram roads and electrical network of the center of Belgrade, in order to include new trams;

- Adaptation, modernization, extension of the most important traffic roads, in order to enable the most circulating traffic possible;

- Purchase of the 30 new and modernized tram vehicles.

As a phase of continuation and finalization of the project, an additional 15 million euros will be provided for the continuation of investments in the area of expanding Belgrade's traffic infrastructure. Regarding the city transport in Belgrade, the City Administration of Belgrade and the City Transportation Company "Belgrade" (hereinafter "GSP") will review their regulatory relations and bring them in harmony with the best commercial practices in the world.

\section{Financing the project}

EBRD participates in the financing of the project with a total of 166, 452 million euros, of which:

- "Original loan" in the amount of 57 million euros (November 2011);

- First loan increase in the amount of 30 million euros (July 2013);

- Second loan increase in the amount of 15 million euros (in July 2017).

Estimated project costs amount to 227,032 million euros. In addition to the EBRD financing, the City of Belgrade will co-finance the implementation of the public transport strategy and the construction of transport infrastructure from its own funds.

According to the GSP business program for 2017 and 2018, the table shows the credit indebtedness table (www.gsp.rs):

Table 4. Credit Indebtedness of GSP (Business Program for 2018)

\begin{tabular}{|c|c|c|c|c|c|c|c|c|c|c|c|c|}
\hline $\begin{array}{l}\stackrel{0}{0} \\
\stackrel{0}{0} \\
\stackrel{0}{0}\end{array}$ & 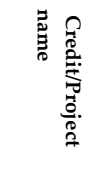 & 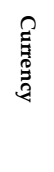 & 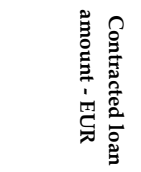 & 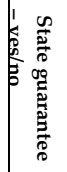 & 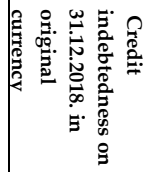 & 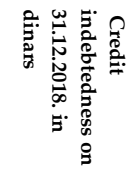 & 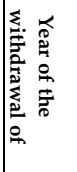 & 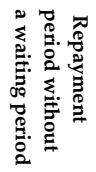 & 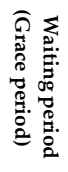 & 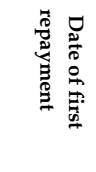 & 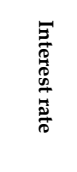 & 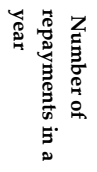 \\
\hline \multicolumn{13}{|c|}{ Domestic creditor } \\
\hline AIK bank & $\begin{array}{l}\text { Overdraf } \\
t\end{array}$ & din & $\begin{array}{l}400.000 .000,0 \\
0\end{array}$ & No & $\begin{array}{l}400.000 .000,0 \\
0\end{array}$ & $\begin{array}{l}400.000 .000,0 \\
0\end{array}$ & 2017 & $\begin{array}{l}12 \\
\text { months }\end{array}$ & - & - & $\begin{array}{l}3.8 \% \\
+ \\
\text { belibo } \\
\mathrm{r}\end{array}$ & $\begin{array}{l}\text { After the } \\
\text { expiratio } \\
n \text { of the } \\
\text { loan }\end{array}$ \\
\hline AIK bank & $\begin{array}{l}\text { Overdraf } \\
t\end{array}$ & din & $\begin{array}{l}400.000 .000,0 \\
0\end{array}$ & No & $\begin{array}{l}400.000 .000,0 \\
0\end{array}$ & $\begin{array}{l}400.000 .000,0 \\
0\end{array}$ & 2017 & $\begin{array}{l}12 \\
\text { months }\end{array}$ & - & - & $\begin{array}{l}3.8 \% \\
+ \\
\text { belibo } \\
\mathrm{r}\end{array}$ & $\begin{array}{l}\text { After the } \\
\text { expiratio } \\
\mathrm{n} \text { of the } \\
\text { loan }\end{array}$ \\
\hline $\begin{array}{l}\text { Unicredit } \\
\text { bank }\end{array}$ & $\begin{array}{l}\text { Overdraf } \\
t\end{array}$ & din & $\begin{array}{l}600.000 .000,0 \\
0\end{array}$ & No & $\begin{array}{l}600.000 .000,0 \\
0\end{array}$ & $\begin{array}{l}600.000 .000,0 \\
0\end{array}$ & 2017 & $\begin{array}{l}12 \\
\text { months }\end{array}$ & - & - & $\begin{array}{l}3.8 \% \\
+ \\
\text { belibo } \\
\mathrm{r}\end{array}$ & $\begin{array}{l}\text { After the } \\
\text { expiratio } \\
n \text { of the } \\
\text { loan }\end{array}$ \\
\hline
\end{tabular}




\begin{tabular}{|c|c|c|c|c|c|c|c|c|c|c|c|c|}
\hline $\begin{array}{l}\text { Vojvođans } \\
\text { ka bank }\end{array}$ & $\begin{array}{l}\text { Overdraf } \\
t\end{array}$ & din & $\begin{array}{l}400.000 .000,0 \\
0\end{array}$ & No & $\begin{array}{l}400.000 .000,0 \\
0\end{array}$ & $\begin{array}{l}400.000 .000,0 \\
0\end{array}$ & 2017 & $\begin{array}{l}12 \\
\text { months }\end{array}$ & - & - & $\begin{array}{l}3.8 \% \\
+ \\
\text { belibo } \\
\mathrm{r}\end{array}$ & $\begin{array}{l}\text { After the } \\
\text { expiratio } \\
\mathrm{n} \text { of the } \\
\text { loan }\end{array}$ \\
\hline $\begin{array}{l}\text { Vojvođans } \\
\text { ka bank }\end{array}$ & $\begin{array}{l}\text { Overdraf } \\
t\end{array}$ & din & $\begin{array}{l}200.000 .000,0 \\
0\end{array}$ & No & $\begin{array}{l}200.000 .000,0 \\
0\end{array}$ & $\begin{array}{l}200.000 .000,0 \\
0\end{array}$ & 2017 & $\begin{array}{l}12 \\
\text { months }\end{array}$ & - & - & $\begin{array}{l}3.8 \% \\
+ \\
\text { belibo } \\
\mathrm{r}\end{array}$ & $\begin{array}{l}\text { After the } \\
\text { expiratio } \\
\mathrm{n} \text { of the } \\
\text { loan }\end{array}$ \\
\hline $\begin{array}{l}\text { Belgrade } \\
\text { power } \\
\text { plants }\end{array}$ & $\begin{array}{l}\text { Loan } \\
\text { agreeme } \\
\text { nt }\end{array}$ & Din & $\begin{array}{l}400.000 .000,0 \\
0\end{array}$ & No & $\begin{array}{l}400.000 .000,0 \\
0\end{array}$ & $\begin{array}{l}400.000 .000,0 \\
0\end{array}$ & 2016 & 12months & - & - & $3 \%$ & $\begin{array}{l}\text { After the } \\
\text { deadline } \\
\text { expiratio } \\
n\end{array}$ \\
\hline $\begin{array}{l}\text { City } \\
\text { markets }\end{array}$ & $\begin{array}{l}\text { Loan } \\
\text { agreeme } \\
\text { nt }\end{array}$ & Din & $\begin{array}{l}280.000 .000,0 \\
0\end{array}$ & No & $\begin{array}{l}280.000 .000,0 \\
0\end{array}$ & $\begin{array}{l}280.000 .000,0 \\
0\end{array}$ & 2016 & 12 months & - & - & $3 \%$ & $\begin{array}{l}\text { After the } \\
\text { deadline } \\
\text { expiratio } \\
n\end{array}$ \\
\hline $\begin{array}{l}\text { Belgrade } \\
\text { Water } \\
\text { system }\end{array}$ & $\begin{array}{l}\text { Loan } \\
\text { agreeme } \\
\text { nt }\end{array}$ & Din & $\begin{array}{l}300.000 .000,0 \\
0\end{array}$ & No & $\begin{array}{l}300.000 .000,0 \\
0\end{array}$ & $\begin{array}{l}300.000 .000,0 \\
0\end{array}$ & 2016 & 12 months & - & - & $3 \%$ & $\begin{array}{l}\text { After the } \\
\text { deadline } \\
\text { expiratio } \\
n\end{array}$ \\
\hline $\begin{array}{l}\text { Leasing- } \\
\text { Unicredit } \\
\text { leasing - } \\
\text { bus } 31\end{array}$ & Leasing & Eur & $6.912 .000,00$ & No & 0.00 & 0.00 & 2013 & 5years & & $\begin{array}{l}08.04 .201 \\
3 .\end{array}$ & 8.41 & 12 \\
\hline $\begin{array}{l}\text { Leasing- } \\
\text { Unicredit } \\
\text { leasing - } \\
\text { van } 10\end{array}$ & Leasing & Eur & $424.560,00$ & No & $18.910,00$ & $2.458 .300,00$ & 2014 & 5 years & & $\begin{array}{l}01.04 .201 \\
4 .\end{array}$ & 9,6023 & 12 \\
\hline $\begin{array}{l}\text { Leasing- } \\
\text { Unicredit } \\
\text { leasing - } \\
\text { bus } 30\end{array}$ & Leasing & Eur & $5.400 .000,00$ & No & $2.007 .363,60$ & $\begin{array}{l}260.957 .268,0 \\
0\end{array}$ & 2015 & 5 years & & $\begin{array}{l}08.10 .201 \\
5 .\end{array}$ & 10,83 & 12 \\
\hline $\begin{array}{l}\text { S leasing - } \\
20 \text { buses }\end{array}$ & Leasing & Eur & $3.820 .800,00$ & No & $1.827 .518,00$ & $\begin{array}{l}237.577 .444,0 \\
0\end{array}$ & 2016 & 5 years & & $\begin{array}{l}03.10 .201 \\
6 .\end{array}$ & 7.75 & 12 \\
\hline $\begin{array}{l}\text { Leasing- } \\
\text { Unicredit } \\
\text { leasing - } \\
\text { bus } 10\end{array}$ & Leasing & Eur & $1.918 .800,00$ & No & $1.103 .424,80$ & $\begin{array}{l}143.445 .224,0 \\
0\end{array}$ & 2017 & 5 years & & $\begin{array}{l}08.05 .201 \\
7 .\end{array}$ & 9.31 & 12 \\
\hline $\begin{array}{l}\text { Leasing - } \\
30 \\
\text { articulated } \\
\text { buses }\end{array}$ & Leasing & Eur & $8.636 .400,00$ & No & $5.370 .220,80$ & $\begin{array}{l}698.128 .704,0 \\
0\end{array}$ & 2017 & 5 years & & $\begin{array}{l}20.07 .201 \\
7 .\end{array}$ & 9 & 12 \\
\hline \multicolumn{13}{|c|}{ Foreign creditor } \\
\hline EBRD & $\begin{array}{l}\text { Buying } \\
200 \\
\text { buses }+ \\
12 \\
\text { minibuse } \\
\mathrm{s}\end{array}$ & Eur & $49.981 .906,00$ & & $27.770 .259,70$ & $\begin{array}{l}3.776 .755 .319 \\
20\end{array}$ & 2013 & 9 & 2 & $\begin{array}{l}30.03 .201 \\
5 .\end{array}$ & $\begin{array}{l}4.5+ \\
6 \mathrm{ME}\end{array}$ & 2 \\
\hline EBRD & & Din & $\begin{array}{l}1.803 .265 .500 \\
00\end{array}$ & & $\begin{array}{l}\text { 1.746.550.356, } \\
03\end{array}$ & $\begin{array}{l}\text { 1.746.550.356, } \\
03\end{array}$ & 2017 & 6 & $\begin{array}{l}8 \\
\text { month } \\
\mathrm{s}\end{array}$ & $\begin{array}{l}30.09 .201 \\
7 .\end{array}$ & $\begin{array}{l}2,8+ \\
3 \mathrm{~m} \\
\text { belibo } \\
\mathrm{r}\end{array}$ & 4 \\
\hline \multicolumn{7}{|c|}{ Total credit indebtedness } & \multicolumn{2}{|c|}{$\begin{array}{l}\text { 9.845.872.615, } \\
00\end{array}$} & & & & \\
\hline \multicolumn{7}{|c|}{ Of which for liquidity } & \multicolumn{2}{|c|}{$\begin{array}{l}2.000 .000 .000, \\
00\end{array}$} & & & & \\
\hline \multicolumn{7}{|c|}{ Of which for capital projects } & \multicolumn{2}{|c|}{$\begin{array}{l}1.342 .566 .940 \\
00\end{array}$} & & & & \\
\hline
\end{tabular}


Table 5. Loan Payment Plan to the EBRD - GSP (Business Program for 2018)

\begin{tabular}{|c|c|c|c|c|c|c|c|}
\hline $\begin{array}{l}\text { Principal } \\
\text { amount } \\
\text { first } \\
\text { quarter }\end{array}$ & $\begin{array}{l}\text { Principal } \\
\text { amount } \\
\text { second } \\
\text { quarter }\end{array}$ & $\begin{array}{l}\text { Principal } \\
\text { amount } \\
\text { third } \\
\text { quarter }\end{array}$ & $\begin{array}{l}\text { Principal } \\
\text { amount } \\
\text { fourth } \\
\text { quarter }\end{array}$ & $\begin{array}{l}\text { Interest } \\
\text { first } \\
\text { quarter }\end{array}$ & $\begin{array}{l}\text { Interest } \\
\text { second } \\
\text { quarter }\end{array}$ & $\begin{array}{l}\text { Interest } \\
\text { third } \\
\text { quarter }\end{array}$ & $\begin{array}{l}\text { Interest } \\
\text { fourth } \\
\text { quarter }\end{array}$ \\
\hline $\begin{array}{r}289.767 .96 \\
4,12 \\
\end{array}$ & & $\begin{array}{r}289.767 .96 \\
4,12 \\
\end{array}$ & & $\begin{array}{r}78.777 .14 \\
1,84 \\
\end{array}$ & & $\begin{array}{r}71.686 .92 \\
9,92 \\
\end{array}$ & \\
\hline $\begin{array}{r}78.402 .847 \\
, 83 \\
\end{array}$ & $\begin{array}{r}78.402 .84 \\
7,83 \\
\end{array}$ & $\begin{array}{r}78.402 .847 \\
, 83 \\
\end{array}$ & $\begin{array}{r}78.402 .84 \\
7,83 \\
\end{array}$ & $\begin{array}{r}39.097 .15 \\
2,17 \\
\end{array}$ & $\begin{array}{r}39.097 .15 \\
2,17 \\
\end{array}$ & $\begin{array}{r}39.097 .15 \\
2,17 \\
\end{array}$ & $\begin{array}{r}39.097 .15 \\
2,17 \\
\end{array}$ \\
\hline
\end{tabular}

With this, according to the Income Statement, the results for the period 2014 - 2017 are as follows:

GSP (Source APR)

Calculation:

(AOP 1064: S. NET PROFIT OR AOP 1065: T. NET LOSS) / AOP 1001: A. OPERATING INCOME

Table 6. Profit margin

\begin{tabular}{lccc}
\hline Net profit & Net loss & $\begin{array}{c}\text { Business } \\
\text { Income }\end{array}$ & $\begin{array}{c}\text { Profit } \\
\text { margin }\end{array}$ \\
\hline $\mathbf{2 0 1 4}$ & 620306000 & 13762161000 & $-40.2 \%$ \\
\hline $\mathbf{2 0 1 5}$ & 1340493000 & 13484630000 & $-4 \%$ \\
\hline $\mathbf{2 0 1 6}$ & & & \\
\hline $\mathbf{2 0 1 7}$ & 551583000 & 13751206000 & $-99.4 \%$ \\
\hline
\end{tabular}

Source : Knežević et al. (2017)

Table 7. Return on equity rate ( $R O E)$

\begin{tabular}{|c|c|c|c|c|}
\hline & Net profit & Net loss & Capital & ROE \\
\hline 2014 & & 620306000 & 11095454000 & $-41.23 \%$ \\
\hline 2015 & & 1340493000 & 15525893000 & $-3.55 \%$ \\
\hline 2016 & & 551583000 & 14632704000 & $-9.16 \%$ \\
\hline 2017 & & 4574888000 & 13987532000 & $-4.43 \%$ \\
\hline
\end{tabular}


Table 8. Return on assets rate (ROA)

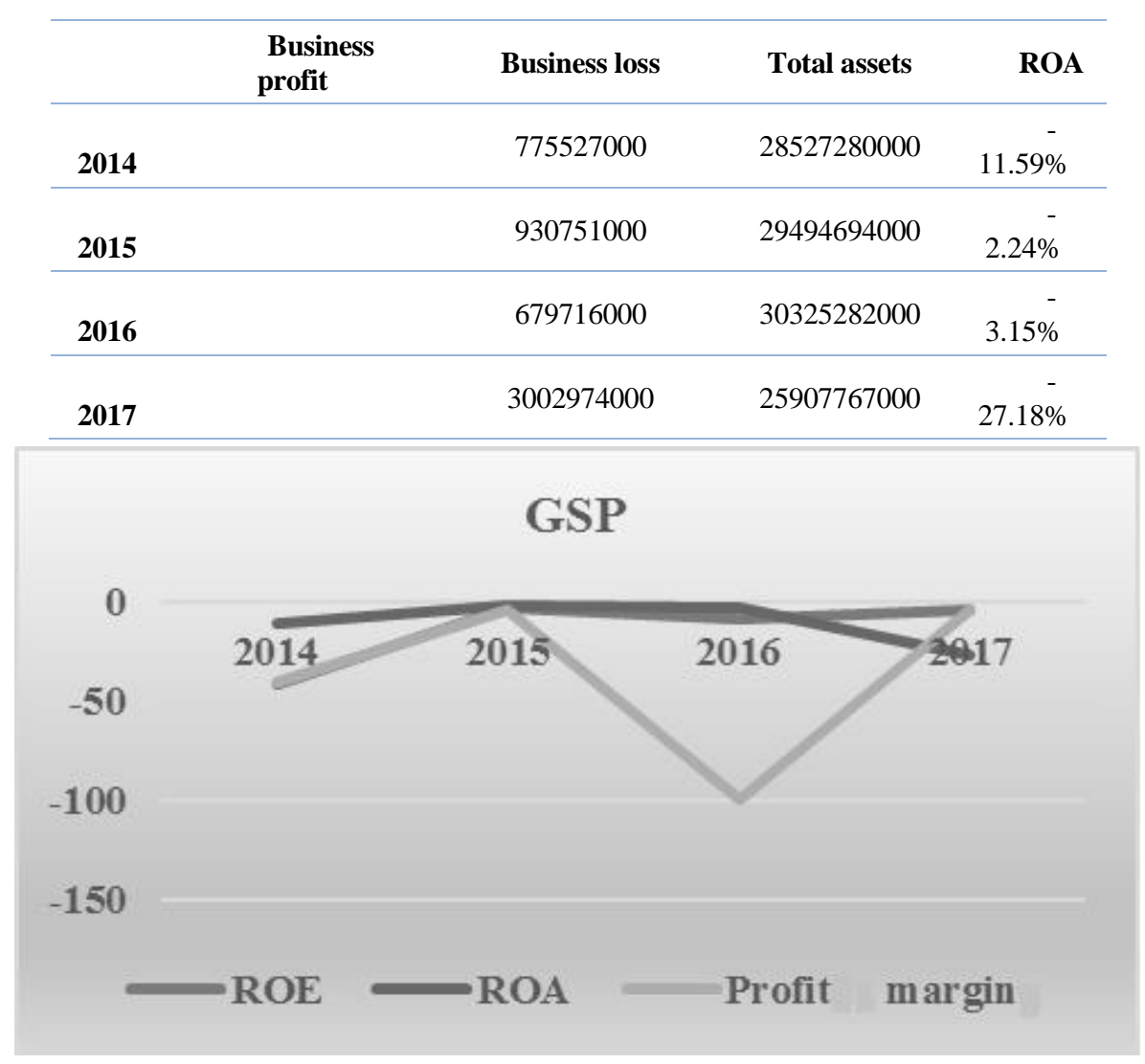

Figure 4. GSP's rate of return

Total credit indebtedness is high. It must be taken into account that the profit margin in 2014 and 2016 was large in percentage, in the negative aspect, respectively, in 2014 to $-40.2 \%$ and in 2016 to $-99.4 \%$.

We have to keep in mind that this kind of investment in the GSP can help the company enter the restructuring process in the coming years. According to the revenues for 2017, which amounted to about 5.4 billion dinars from the core business, it is concluded that, according to the operating parameters shown, a longer interval of return of the existing debts is required.

\section{COOPERATION WITH EBRD}

EBRD loans are based on interest rates that are at a relatively lower level than the current market prices of capital. It should be emphasized that the EBRD does not finance projects in its entirety, but only partially, offering fixed and variable interest rates:

- A fixed interest rate associated with a variable rate such as LIBOR.

- A floating rate with a cap or collar.

Since the interest rate affects profitability, the financial structure of the project should include loans with variable and fixed interest rates. Their combination is assessed with regard to the sensitivity of the client and the project to the movement of interest rates, ie. to the estimated interest risk of the project. 


\section{Fees and expenses}

An additional margin is envisioned at the base interest rate, which is a combination of national risk and project-specific risk.

With the margin, the EBRD may charge some of the following fees and commissions:

- Front-end commission, paid in advance.

- Fee for payment of obligations, which is paid for the pre-loan, but also the unpaid loan amount.

- Loan conversion fees, payable at the time of the interest rate or before the currency arrangement on the amount to be converted.

- Fees for advance payment, cancellation and late payment are charged as needed.

In accordance with commercial practice, sponsors are obliged to compensate the bank for exit costs, such as fees for technical advisors, lawyers and travel expenses.

\section{Other terms of lending}

Full credit terms are negotiated directly with the client for each project.

\section{Recourse}

It is not required to obtain a sponsor. However, the EBRD may require special enforcement guarantees, as well as other forms of sponsorship of the type that are commonly used in limited access financing practices.

\section{Insurance}

The bank requires project companies to obtain insurance against normal insurance risks. Examples include property theft, fire outbreaks, and specific construction risks. The EBRD does not require insurance against political risk or non-convertibility of the domestic currency.

\section{Security}

The EBRD usually requires companies that it approves a loan to, to provide a mortgage for loan securing, taking into account, on average, large amounts of approved loans and their relatively long repayment periods.

Security may also include:

1. Mortgage on immovable property, such as land, facilities and other buildings.

2. Lien of movable property, such as equipment, other business assets.

3. Lien of deposit in hard currency and earnings in the local currency of the company.

4. Promise the sponsor's shares in the company.

5. Provision of insurance policies for the company and other contractual benefits.

\section{Syndication}

As part of the loan package, typical contracts on project financing are provided. It is also possible to syndicate the loan, ie. ensuring participation of more participants in order to limit indebtedness and determine other financial measures and various other issues. 


\section{Loan repayment}

Repayment of loans provided by the EBRD takes place usually in equal, semi-annual installments. Further deadlines can be considered exceptionally, for example, up to 15 years for large infrastructure operations-projects.

\section{Possibilities of risk protection}

The Bank can assist in managing the financial risks associated with assets and in the obligations of the project. This includes currency risk, interest rate risk and commodity price risk. Risk protection instruments include currency swaps, interest swaps, caps, collars and options and commodity swaps.

\section{Loans for smaller projects}

Projects that are too small to be funded directly by the EBRD can still benefit from the EBRD investment.

The EBRD supports local commercial banks, which in turn provide loans to small and medium-sized enterprises and municipalities. Tools that may be available include credit lines, bank loans, credit facilities, and investments in local banks.

Small and medium-sized enterprises should contact local banks directly to access financing and check local requirements and investment restrictions. Loans to micro, small and mediumsized enterprises are available from these banks throughout the EBRD region.

Companies wishing to obtain loans through local banks should ensure:

1. Healthy business plans for establishing or expanding the company's business.

2. Strong management of the company with proven results.

3. Products that are competitive on the market.

4. Information about owners/partners.

5. Financial and credit history

6. Security in the form of mortgages, liens, etc.

Projects in Serbia and the world are based on the EBRD's investment in every potential possible and in significant transitional progress, an increase in living standards, and conditions for building a healthy business environment. Thanks to the capabilities of the European Bank for Reconstruction and Development, and that they can always co-finance projects with other project financiers and enable the recipient company and the beneficiary of the loan to have the potential to access cash funds, thus fulfilling the achievement of all business goals. It should be emphasized that with business entities that have signed a financing agreement with the EBRD, which in the past years performed the evaluation of almost all these economic entities, the funds received from the loan tranche immediately were invested in further improving of the existing service and product, and very few of these funds go to repay, for example, the already existing debts of those companies, which they have with potential suppliers and other partners. This part does not apply to the EBRD, or to other financer participants in the project, but a large part is related to the decisions of the borrower's management. In the large scale, they are the enterprises themselves. 
Therefore, see a table that is an example of the basis and purpose of cooperation:

Table 9. An example of the basis and purpose of cooperation with the EBRD in Serbia ${ }^{2}$

\begin{tabular}{|c|c|c|c|}
\hline Clients & $\begin{array}{c}\text { Amount } \\
\text { Eur }\end{array}$ & Description & Year \\
\hline SRBIJA VOZ & $22.000 .000,00$ & Infrastructure reconstruction & 2017 \\
\hline ŽTP SRBIJA & $57.000 .000,00$ & Infrastructure reconstruction & 2011 \\
\hline AGRI EUROPE & $120.000 .000,00$ & Buying facilities and production infrastructure renewal & 2016 \\
\hline BAKERY POINT & $15.000 .000,00$ & Cancelled & 2009 \\
\hline SOKO ŠTARK & $10.000 .000,00$ & Modernization & 2006 \\
\hline SOMBOLED & $10.000 .000,00$ & Equipment and reconstruction & 2006 \\
\hline FRIKOM & $12.500 .000,00$ & Modernization & 2003 \\
\hline SBB MREZE & $17.000 .000,00$ & Modernization & 2004 \\
\hline ETV & $24.000 .000,00$ & Modernization & 2014 \\
\hline SRBIJA GAS & $150.000 .000,00$ & Organizational and financial reconstruction & 2009 \\
\hline TRANS NAFTA & $5.700 .000,00$ & Cancelled & 2012 \\
\hline KREF & $2.000 .000,00$ & Capital & 2001 \\
\hline TOTAL & $445.000 .000,00$ & Based on expansion, renewal and modernization & Until 2018 \\
\hline
\end{tabular}

We are basing the research that there are participants in the infrastructure sector of the Republic of Serbia (private and public), who can improve their business through loans from the EBRD that would repay their debts to existing creditors. We think that the public opinion and the mentioned business participants are not informed to the extent that they can create such a business environment, which would enable the relaxation of their business obligations over a longer period of time and the possibility of realizing their business plans and models. Our business stakeholders, the business and the public opinion, must recognize the potential of the EBRD to a greater extent.

In order to define the final list of relevant indicators, which will be included in the assessment of the level of knowledge of the area of EBRD investment in the infrastructure sector of Serbia, it is necessary to implement the so-called expert judgment in the next step. The number of experts who participated in this research was 7. It was also accepted that the weight coefficients of the experts are equal and equal to 1 . The experts were given a questionnaire in the form of a table, which was to be filled in according to the attached instruction from the questionnaire. An expert evaluation would involve evaluating indicators that are in a narrow list of possible relevant indicators.

It is necessary, based on the experts' opinion, to determine the indicators that have the greatest impact on the calculation of the level of knowledge of the area of EBRD's investment in the infrastructure sector of Serbia.

The assigned degrees of knowledge (rank of knowledge) are arranged in the following way:

\begin{tabular}{|c|c|c|c|c|}
\hline 1 & 2 & 3 & 4 & 5 \\
\hline no & somewhat & medium & quite & yes \\
\hline
\end{tabular}

\footnotetext{
${ }^{2}$ Own sources of the author, data taken from EBRD's site
} 
The calculation of the "rank of knowledge" was carried out as follows.

The calculation of the expert judgment for each of the risk behaviors was done as follows:

Table 10. Calculation procedure for the final expert evaluation

\begin{tabular}{|l|l|l|}
\hline \multicolumn{3}{|l|}{ Knowledge rank 1 } \\
\hline Expert 1 & Expert 2 & Expert n \\
\hline Rating 1 & Rating 2 & Rating n \\
\hline Total rating & & \\
\hline
\end{tabular}

By calculating the overall rate (degree of knowledge) of the EBRD's investment area in the Serbian infrastructure sector, the next step is where each category of knowledge is multiplied with an appropriate level of knowledge, and the weighting factors (WF) are observed for the whole country. Then, the addition of weighting factors for each area was carried out, and a "rank of knowledge" was obtained for each site observed.

$\mathrm{WF}$ Belgrade $=\mathrm{A} * \mathbf{1}+\mathrm{B} * \mathbf{3}+\mathrm{V} * \mathbf{1}+\mathrm{G} * \mathbf{5}+\cdots+\mathrm{NJ} * \mathbf{1}$

"Knowledge Rank" = WF Beograd + WF Novi Sad + $\cdots+$ WF Subotica

After executing the weighting, the data obtained indicate which of the mentioned areas has the highest degree of recognition of the importance of EBRD's investments in our country and submit a proposal for an idea solution in order to improve the understanding of the importance of cooperation with the EBRD and the proposal for future cooperation. The database was tailored for research needs in Microsoft Office Excel 2013, in which tables were created and generated the required charts.

Table 11. Table showing investments in the territory of the Republic of Serbia and assigned degrees of knowledge and importance

\begin{tabular}{|l|l|}
\hline \multicolumn{2}{|c|}{ Investments on the territory of the Republic of Serbia } \\
\hline $\begin{array}{l}\text { 1. Are you familiar with the degree of development of the } \\
\text { infrastructure sector in Serbia and how important is it, in your } \\
\text { opinion? }\end{array}$ & 1 \\
\hline $\begin{array}{l}\text { 2. Do you understand the role of the EBRD in the development of } \\
\text { Serbia's infrastructure sector and how important is it in your } \\
\text { opinion? }\end{array}$ & 1 \\
\hline $\begin{array}{l}\text { 3. Do you know how the EBRD invests in the economy and } \\
\text { infrastructure of the Republic of Serbia and how important is it in } \\
\text { your opinion? }\end{array}$ & 4 \\
\hline $\begin{array}{l}\text { 4. Do you know some major investors (international financial } \\
\text { institutions) in the infrastructure sector in Serbia and how } \\
\text { important are investments in your opinion? }\end{array}$ & 4 \\
\hline $\begin{array}{l}\text { 5. Do you think that the effects of investments in Serbia's } \\
\text { economy (especially in the infrastructure sector) are satisfying? }\end{array}$ & 4 \\
\hline $\begin{array}{l}\text { 6. Do you know the amount of the EBRD's up-to-date investment in } \\
\text { the infrastructure sector and how important is it in your opinion? }\end{array}$ & 4 \\
\hline $\begin{array}{l}\text { 7. Are you familiar with the cooperation between EBRD and local } \\
\text { institutions on projects: corridor X, bridge on Ada, renovation of } \\
\text { railway infrastructure? }\end{array}$ & 4 \\
\hline
\end{tabular}




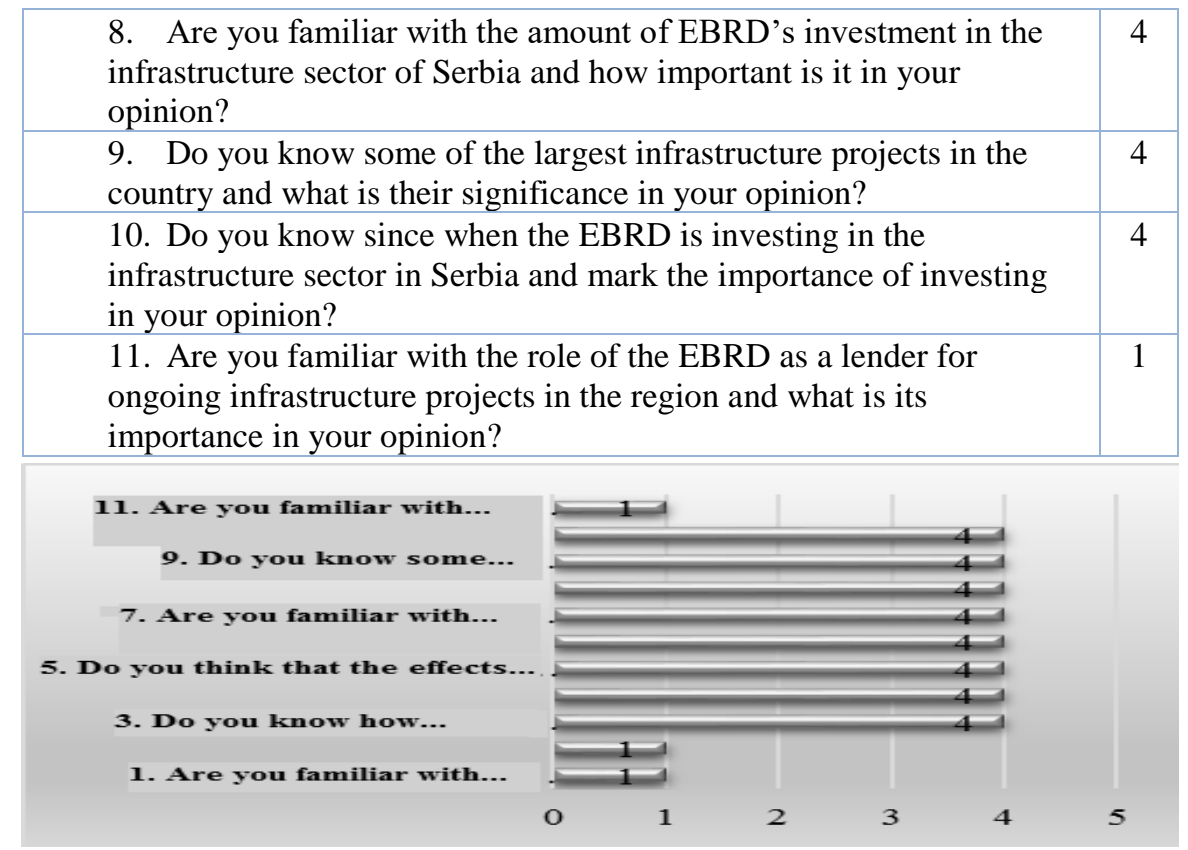

Graph 1. Graphic presentation of the overall rate of investment experts on the territory of the Republic of Serbia, based on the degree of knowledge and importance

It can be concluded from the graph that the following investments are the most important according to the experts: claims $2,3,4,5,6,7,8,9$, and 10 .

Table 12. The value of weighted estimates of the importance of investment in the cities of the research

\begin{tabular}{|c|c|c|c|c|} 
& Beograd & Novi Sad & Subotica & Niš \\
\hline Claim 1 & 16 & 80 & 13 & 36 \\
\hline Claim 2 & 16 & 48 & 14 & 26 \\
\hline Claim 3 & 84 & 60 & 30 & 18 \\
\hline Claim 4 & 100 & 19 & 72 & 115 \\
\hline Claim 5 & 104 & 60 & 66 & 19 \\
\hline Claim 6 & 108 & 15 & 80 & 100 \\
\hline Claim 7 & 100 & 16 & 51 & 110 \\
\hline Claim 8 & 96 & 20 & 17 & 130 \\
\hline Claim 9 & 92 & 13 & 57 & 44 \\
\hline Claim 10 & 104 & 20 & 84 & 105 \\
\hline Claim 11 & 15 & 88 & 30 & 16 \\
\hline
\end{tabular}

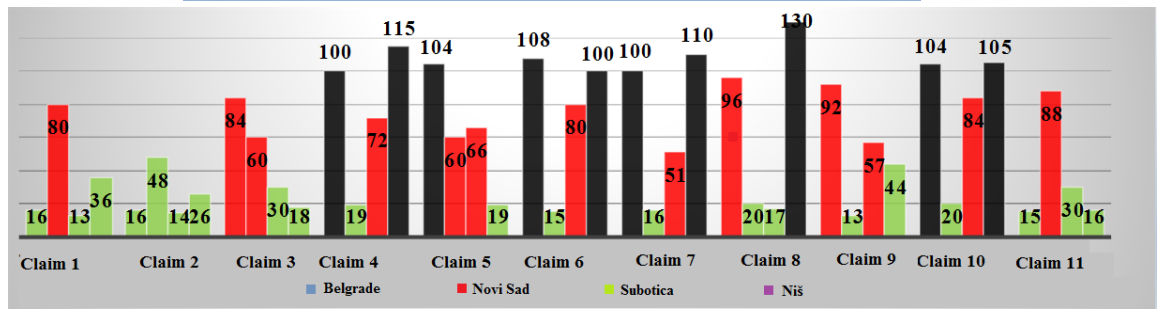

Graph 2. The distribution of the weighted values of the investment grade value of the research cities, observed for the four cities

From the Table 12, it can be concluded that the claims 2, 3, 4, 5, 6, 7, 8, 9 and 10 are primary in Belgrade, while for Novi Sad are the claims 1 and 11. For Subotica those are 6 and 10, and for Niš 4, 6, 7, 8. Aforementioned claims are presented on a graph below. 


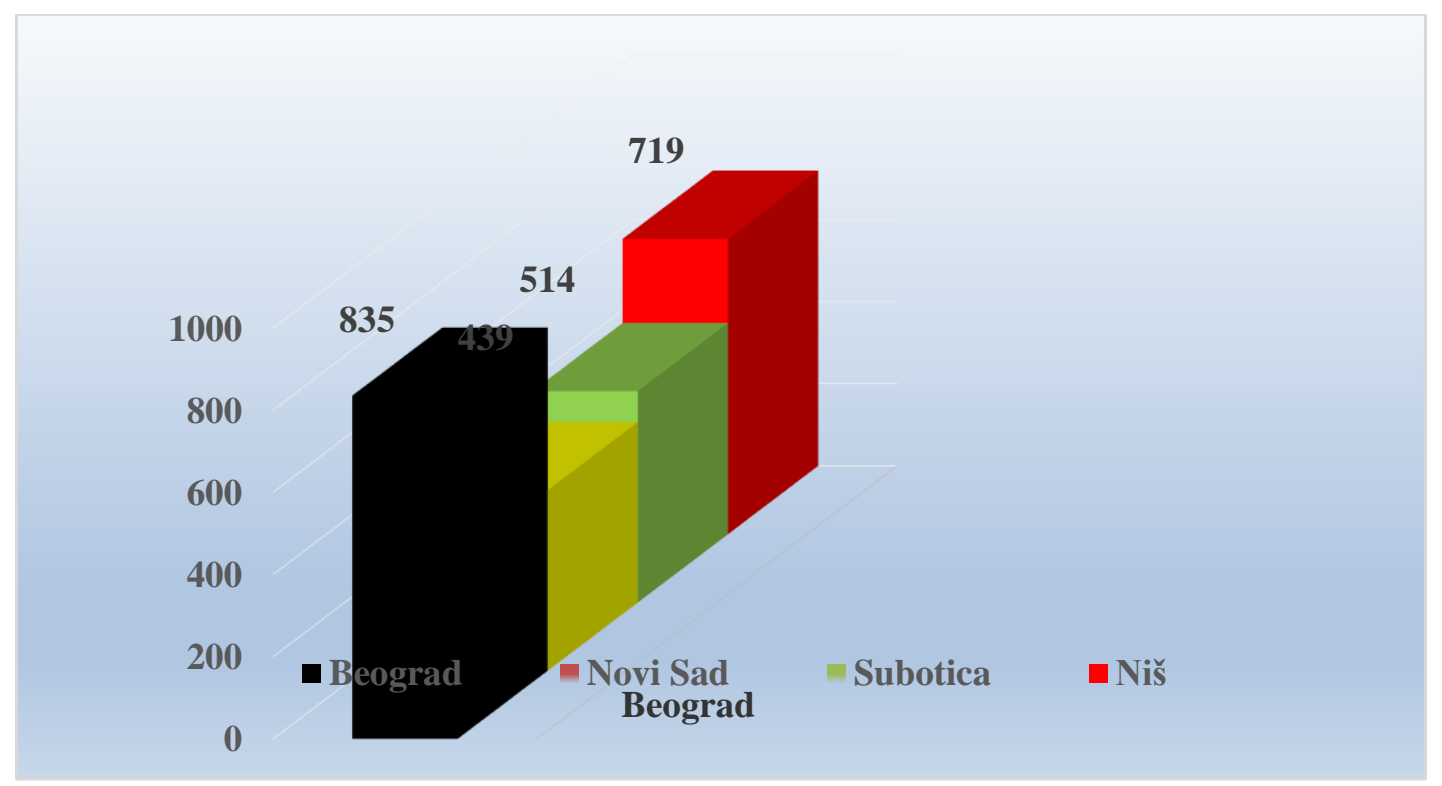

Graph 3. The distribution of the total weighted values of the investment grade value of the research cities, observed for the four cities

From this chart it can be clearly seen that the city of Belgrade has the highest level of knowledge of the importance of the EBRD investing in our country, and that it is followed by Novi Sad with a significantly lower degree.

Each class of weighting factors is assigned a color: black $(100 \geq \mathrm{TF})$ - very high value, red $(50 \geq \mathrm{TF}<99)$ - high value, green $(1 \geq \mathrm{TF}<49)$ - low value. From the chart it can be noted that 4 , $6,7,10$ are the claims that are distinguished with the highest degree of knowledge in the observed cities.

EBRD has invested around 806 million euros in Serbian infrastructure, for a period of about 7 years.

Total investments that have been realized for the last 7 years and which have been signed and in the process of implementation, for which the funds have already been taken over in the domain of the infrastructure sector and the funds planned, amount to over 1,093 million euros. This amount is changeable because new projects and applications change in a short time interval. In accordance with this, we see the following:

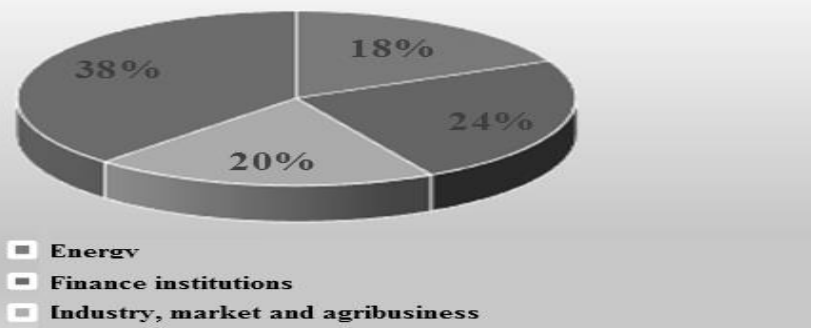

Graph 4. Percentage of EBRD's investment in infrastructure

Source: https://www.ebrd.com/where-we-are/serbia/data.html 
Table 13. Investment of the Republic of Serbia in the traffic infrastructure

\begin{tabular}{cccccc}
\hline $\mathbf{2 0 1 2 .}$ & $\mathbf{2 0 1 3 .}$ & $\mathbf{2 0 1 4}$ & $\mathbf{2 0 1 5 .}$ & $\mathbf{2 0 1 6 .}$ & $\mathbf{2 0 1 7 .}$ \\
\hline $\mathbf{7 6 4 9 6 5 2 8}$ & 66551053 & 76411613 & 106585662 & 109485395 & 110768346 \\
\hline \multicolumn{7}{c}{ Average yearly exchange rate of euro } \\
\hline $\mathbf{1 1 3 , 1 2}$ & 113,13 & 117,30 & 120,73 & 123,11 & 121,33 \\
\hline \multicolumn{7}{c}{} \\
\hline $\mathbf{6 7 6 . 2 4 2 . 2 9 1}$ & 588.270 .600 & 651.420 .400 & 882.743 .220 & 889.329 .827 & 912.951 .000 \\
\hline
\end{tabular}

Source: Statistics yearbook 2016, 2017, 2018.

EBRD's investment of 813.000.000 euros in the infrastructure. For the past 6 years, the Republic of Serbia's investment amounted to 4,600,957,338 euros. The percentage share was approximately $17,6 \%$.

The participation of the European Bank for Reconstruction and Development is not a surprise because almost all larger and numerous projects of the greatest public infrastructure importance go and are implemented through the EBRD. The effects of these investments are reflected in the improved road network, highways, rail network, construction of highways, road stations, power plants, and other infrastructure facilities.

From the point of view of EBRD loans for infrastructure projects, and the participation of the Republic of Serbia, it can be estimated that the projects were profitable. In addition to profitability, the EBRD also takes into account the achievement of other goals such as: engaging the domestic economy, creating new work places in mentioned projects, focusing on the purchase of domestic raw materials, goods, and materials used in the project, the use of domestic logistic houses and services, legal and other agencies. The previous cooperation with the EBRD shows the significance of the mentioned additional goals.

On average, the EBRD does not have a high margin, which in other words points to favorable borrowing terms. We emphasize that we have taken all of the total business in the infrastructure sector and business with Serbia, and this is a favorable moment for us to borrow at not so high interest rates. Especially in the domain of the infrastructure sector, Serbia needs significant investments, and the plan of the Republic of Serbia is that the infrastructure sector is modernized and existing capacities expanded, taking into account the volume of resources that we can obtain and under what conditions. We will present a table overview of the projects that started and initiated the cooperation and on which cooperation was completed, in order to gain insight into these possibilities and comprehensiveness of cooperation in recent years between the EBRD and our business players in the infrastructure sector. 
Table 14. Potential of the investments in the public and private sector

\begin{tabular}{|c|c|c|c|c|}
\hline Date & $\begin{array}{l}\text { Project } \\
\text { number }\end{array}$ & Project name & $\begin{array}{l}\text { Type of } \\
\text { project }\end{array}$ & Project status \\
\hline 20.03.2018. & 46758 & Belgrade solid waste ppp & Private sector & $\begin{array}{l}\text { Project concept accepted - } \\
\text { under consideration }\end{array}$ \\
\hline 24.08.2015. & 47690 & Kragujevac city infrastructure & Public sector & Realized \\
\hline 25.09 .2014 & 46465 & Belgrade water & Public sector & Realized \\
\hline 03.09.2014. & 45458 & Šabac district heating upgrade & Public sector & Cancelled \\
\hline 16.07.2012. & 44014 & $\begin{array}{c}\text { Belgrade bus renewal } \\
\text { programme }\end{array}$ & Public sector & Realized \\
\hline 21.02.2012. & 43472 & $\begin{array}{l}\text { Subotica water upgrade } \\
\text { programme }\end{array}$ & Public sector & $\begin{array}{l}\text { Signed- realization in } \\
\text { progress }\end{array}$ \\
\hline 30.06.2011. & 42809 & Belgrade public transport & Public sector & $\begin{array}{l}\text { Signed- realization in } \\
\text { progress }\end{array}$ \\
\hline 10.01.2011. & 41874 & $\begin{array}{l}\text { Novi sad district heating } \\
\text { project }\end{array}$ & Public sector & Cancelled \\
\hline 15.11.2006. & 37033 & Duboko solid waste & Public sector & Realized \\
\hline 22.09.2005. & 34913 & Sava river crossing & Public sector & Realized \\
\hline 13.07.2001. & 17300 & $\begin{array}{l}\text { Belgrade municipal } \\
\text { infrastructure }\end{array}$ & Public sector & Realized \\
\hline
\end{tabular}

Table 21 shows the potential of these investments; we see that there is primarily a focus on the public sector. However, it seems that the importance of the European Bank for Reconstruction and Development is still not sufficiently recognized, especially in the private sector. Our businessmen, private manufacturing companies, business public opinion have to see how the modern financing system works and a larger industrial step should be launched.

In summary, the advantages of cooperation with the European Bank for Reconstruction and Development from the above mentioned projects are the following:

- A feasible approach to a greater mass of funds and greater mobility of funds to modernize infrastructure capacity and build new ones.

- Establishing respect and knowledge of legislation and clear business procedures as a prerequisite for respecting all legal aspects that contribute to a better project focus.

- Establishment of a professional, quality, certified management of the subject and object of the parent project,

- Provides better connection of all participants in the business, and timely informs everyone, monitoring all stages in the project cycle, rapid processing of requests.

- Finding other co-financiers in the project in case of higher needs,

- Ensuring the project with strong guarantees leads to a significant level of the safety of the project,

- Establishing new models and ways of cooperation, a unique way of communication that was not known to a large number of our business entities, and determination in their application. Giving opportunities for new platforms (SEE PLATFORMS),

- Creating a better investment climate, and the possibility of greater economic integration of business actors at the regional level,

- The potential for granting funds for several business factors, and the incentive for their networking. 
- Insisting on the development of certain sectors of the economy, in our case, the infrastructure sector (roads, bridges, network roads).

- Lower interest rates compared to other sources of financing.

- Economic integration of all member states, both pre-accession and candidate countries.

- The presence and distribution of investments in all spheres of the infrastructure sector,

- Realizing all important economic goals in line with EU goals,

- A large number of business activities are coordinated in order to achieve goals on finalization in negotiating chapters.

- Their presence itself allows for the presence of a large number of foreign investors, and provides, as a rule, better rating of the country.

At the same time, there are certain shortcomings and problems in the cooperation, that also exist on the side of domestic institutions, public private partnerships, and other business factors:

- Initiating certain aspects of cooperation that are contrary to the strategic plan of the framework EU directive, but with need to clarify that it is not the EBRD's domain to implement these directives and goals, but domestic institutions to the sector to which the mentioned aspect of cooperation relates.

- Unintentional spending of funds by the borrower, obviously requiring greater control and additional checks by the European Bank for Reconstruction and Development and controls of other business factors, there must be very good control of funds and cash flows in order to avoid the risk of unintentional spending of funds

- Lack of competitiveness of Serbian enterprises, lack of plans for opening large industrial projects by economic actors from the domestic economy of the Republic of Serbia, but orientation exclusively to foreign investors.

- Political uncertainty in the region contributes to the fact that regional integration projects cannot be carried out at a faster time interval.

- Bank procedures and correlations of cooperation often conflict with domestic bureaucracy, which is quite expected because all countries in transition had these difficulties. They are there to fix the situation and to avoid all the risks in business.

- Availability of project data. Namely, this is only one from a number of problems especially for scientific researches, the bank has its own policy of informing and communicating information according to the procedures and statutes of the bank, and information can't be obtained every time, which is right from the point of view of the bank's operations. But from the point of view of other factors, it's a problem in the sphere of non-correspondence.

- The realization of certain projects in the sectors of infrastructure, energy and natural resources took place slower than expected. Reasons for this include insufficient planning, problems with land expropriation, long tendering procedures and unusually low contracted bids, frequent work breaks and limited capacity for project implementation (EBRD).

- Lack of a clear business strategy with the EBRD by companies at the level of all participants in the business, lack of real business plans, knowledge of the subject matter of the loan plan, insufficient expertise and unreliable business practices.

- Not knowing the concept and scope of the EBRD's business by companies in the infrastructure sector.

- Failure to comply with the project by the borrower most often causes a delay in the project. 
There are opinions that the process of cooperation between the EBRD and domestic economic actors is largely accompanied by challenges, and about that - the challenges of cooperation lie in the following: insufficient protection of property rights, inadequate transparency in the process of granting subsidies, a large number of non-transparent inspections, and parafiscal costs, gap between necessary and existing skills, wastewater management subsector remains the most underdeveloped subsector of water supply infrastructure, delay of the adoption of by-laws, the perception that some investors benefit from operating on unequal grounds. ${ }^{3}$

Naturally, as in other development banks in the world, there are always some projects that are not well implemented to the end, which is expected by every norm of operations, taking into account that the bank has direct and indirect business activities with a large number of business actors. What we can emphasize is that it is a practice that can't be avoided in most cases. Of course, there are always exceptions.

It is not uncommon for project participants, in case they don't have an adequate assessment of the cooperation with the EBRD, to go to other foreign lenders and look for other borrowing terms. Usually these are then more expensive loans for infrastructure projects, because an unfavorable project reference is obtained, and other financial institutions or organizations are very cautiously looking at a new loan and a possible type of cooperation. What we have to repeat and conclude, is that for each type of project there are specific loan repayment principles and interest rates and in most cases they are secret and confidential data. However, in the opinion of various state institutions from the Ministry of Finance, the Ministry of Economy, there is no better evaluation of cooperation from cooperation with the European Bank for Reconstruction and Development. We think that no international institution has (in the last 20 years) provided support in the development of the infrastructure sector and program, as it is the case with the aforementioned development bank of Europe. Presently, its potential under the "Europe 2020" strategy is such that the emphasis on the strategy's completion is precisely on the infrastructure sector.

For the purpose of the orientation, we will look at the next set of average interest rates of other financial institutions in the infrastructure sector:

Table 15. Review of interest rates on infrastructure projects of other financial institutions4

\begin{tabular}{|l|l|l|}
\hline Institution name & Interest rate & $\begin{array}{l}\text { Interest rate increase during the repayment- } \\
\text { max }\end{array}$ \\
\hline $\begin{array}{l}\text { IBRD- International Bank for } \\
\text { Reconstruction and Development }\end{array}$ & $1,02 \%$ & $1,05 \%$ \\
\hline $\begin{array}{l}\text { ADB- Asian Development Bank } \\
\text { IADB- Inter-American Development } \\
\text { Bank }\end{array}$ & $1,00 \%$ & $1,5 \%$ \\
\hline AFDB- African Development Bank & $1,05 \%$ & $1,08 \%$ \\
\hline $\begin{array}{l}\text { AIIB- Asian Infrastructure Investment } \\
\text { Bank }\end{array}$ & $5,86 \%$ & $5,87 \%$ \\
\hline
\end{tabular}

According to credit potential, the closest to the EBRD are IBRD, AIIB and IADB. It can be noted that the credit potential is very high.

\footnotetext{
${ }^{3}$ EBRD document, draft of the strategy for Serbia, 2018-2024, Belgrade, Serbia, page 10

${ }^{4}$ Financial reports IBRD, IADB, AFDB, AIIB
} 


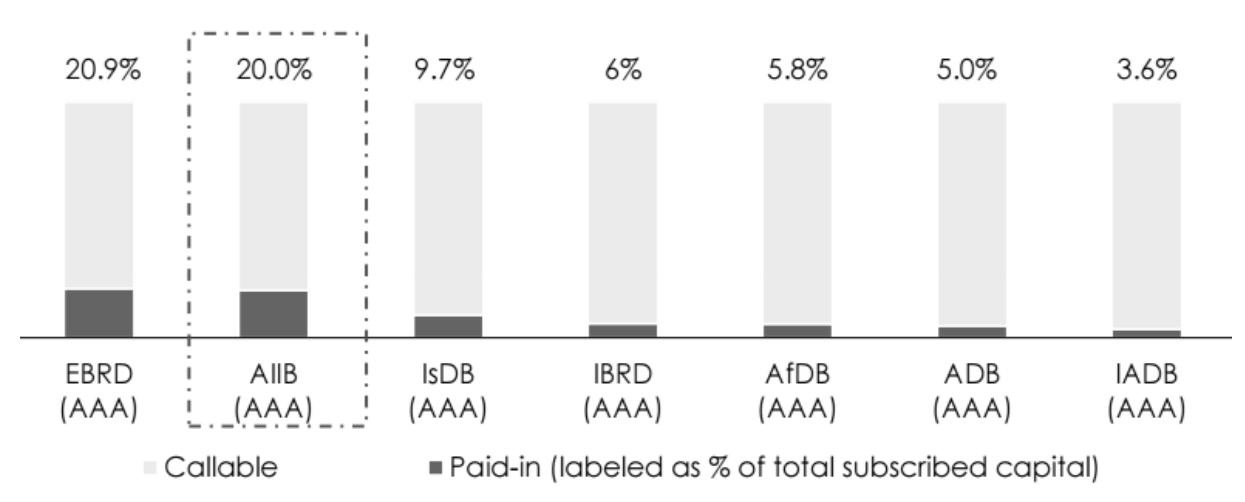

Graph 5. Conservative capital structure

\section{Source Asian Infrastructure Investment Bank}

Until now, investment in the primary and tertiary sector as a function of the European Bank for Reconstruction and Development has been to improve better living conditions and, consequently, certain economic parameters.

Here we are returning to the initial thesis and demonstrate that the EBRD's investments enable the improvement of the conditions of the real and tertiary sector, better conditions for the development of energy efficiency, better infrastructure performance, the development of all favorable aspects of the economy, and, of course, the preservation of the environment.

In all projects shown, as well as on many other projects, we can see exactly this cooperation of the European Bank for Reconstruction and Development with other financial institutions, and as such, deemed very important, because the EBRD thus achieves much greater financial capacity of the projects and increases the security of investments. It attracts other large cofinanciers, and this holds great significance. It is important to emphasize that the usual structure of capitalization, as stated in the European Bank for Reconstruction and Development, is the following: EBRD 35\%, the capital of another big sponsor-financier 25\%, the capital of the local sponsor $15 \%$, and other loans $10 \%$.

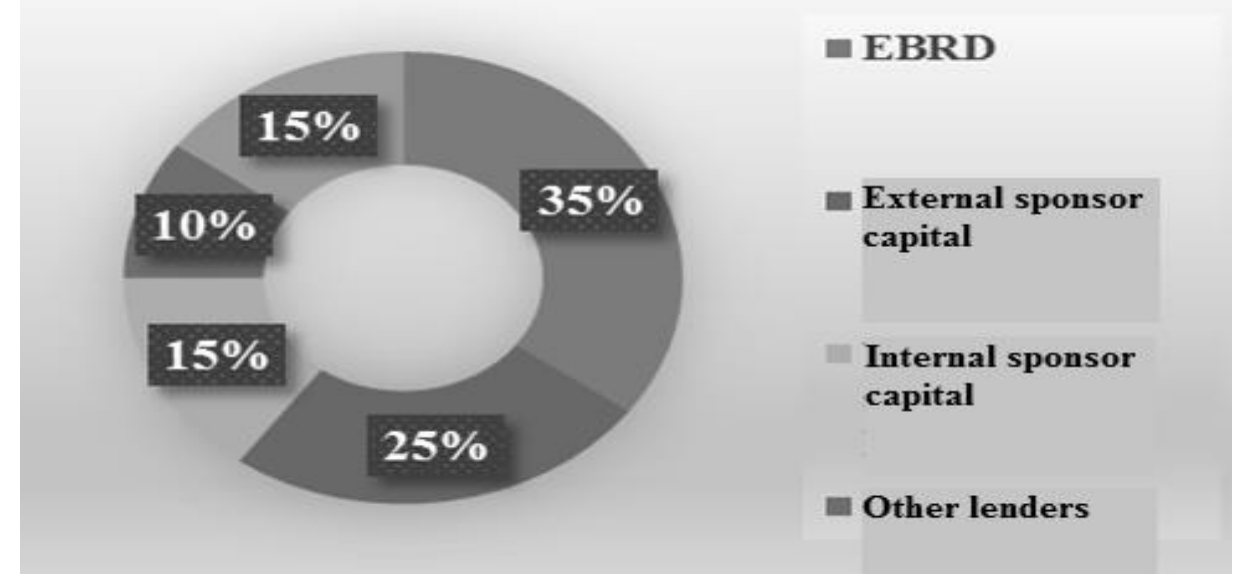

Graph 6. Usual capital structure

Source: Guide to finance EBRD 
According to the financial guidebook "Guide to EBRD financing", the said European bank believes that EBRD loans have a competitive price, based on current market rates, such as EURIBOR and LIBOR. The EBRD also offers fixed and variable interest rates. The EBRD does not subsidize projects, does not offer soft loans and the bank does not compete with private banks' loans ${ }^{5}$.

However, we can't completely agree with this view, because in the current situation in the world and European market of banks, the lower interest rate is the very product of the bank which, as a generic focus, proved to be less attractive and less appealing to potential clientsinvestors. We are not saying that these funds are not competitive by the EBRD, and we are not saying that they are not needed, they are at a very large extent: we just think that interest rates can be even lower. Especially if we take the last EBRD 2013-2017 strategy, in which, according to various analyzes, the financial market and the banking sector have progressed and, consequently, the conditions of the business in the real sector have improved. Overall, the credit rating of the companies in the Republic of Serbia is at a higher level than in the past decade, and therefore the terms should be aligned with it.

However, the demand for debt financing funds by the EBRD (whether it is the European currency or in the dinar currency) has been reduced for several reasons: ${ }^{6}$

- High liquidity of the banking sector and the environment of low interest rates, which made the EBRD's funds less attractive to the ultimate borrowers

- Low demand for long-term finance in dinars

Consequently, there is a decrease in interest for projects of less financial capacity. Therefore, potential debtors consider whether and how much they could finance all loan conditions. But the question remains, who could possibly finance and have as much investment power as EBRD has; our opinion is that the EBRD has exceptional financial and investment power, and at the same time, very large opportunities in the KNOW HOW project segment.

\section{CONCLUSION}

Starting from the hypothetical framework of research, the following can be concluded:

- The European Bank for Reconstruction and Development has recognized its role in providing funds for the infrastructure sector of Serbia. So far, it has been invested in 29 large projects, of which 27 are of public importance, in which 1,291 million euros was invested. This has been largely followed up in line with the main European objectives set by the European Commission, the Council of Europe and other relevant EU bodies. It should be emphasized that, in line with the European economic prosperity lens for the Western Balkans, the main task is to secure a stable economy and development.

- EBRD helps in the infrastructure sector to candidate countries and potential candidates for joining the European Union. It is primarily an important aspect of investing in this sector, as it contributes to improving the infrastructure conditions for easier mobilization, people, equipment and capital.

\footnotetext{
${ }^{5}$ Finance Guidebook: Debt terms, International Finance Institutions and Bilateral loans, page 23, Government of the Republic of Serbia, Office for European Integrations, Belgrade, 2013

${ }^{6}$ EBRD document, draft of the strategy for Serbia, 2018-2024, Belgrade, Serbia, page 7
} 
It is necessary for commercial banks that service credits for the infrastructure sector to take on a more active role in informing entrepreneurs, or potential investors about the funds available to them, and which are part of the credit lines mentioned by the European Bank. In the infrastructure sector there are very strict borrowing conditions, and their position is further aggravated by the global economic crisis. That is why the role of the EBRD in the securing of the funds is of utmost importance for our country.

The infrastructure sector needs extensive investments to address existing shortcomings and overcome the problem of non-maintenance and development breaks. Since the infrastructure sector is one of the important aspects and factors of the development of one society, special attention, importance and all alternative ways of financing, must be given to this domain and therefore must be included in order to ensure uninterrupted and high developmental economic cycles.

We can conclude that the EBRD is the leading financier in the sphere of the infrastructure sector in the Republic of Serbia, reflected in the number of 29 major projects, which are of a very large economic (economy, traffic, infrastructure) significance. Her role was particularly significant in the strategy implementation period of the 2007-2011, 2012-2017, which was an exceptional momentum for the boom of her business in Serbia. In Serbia, there is a very high need for the financing of the infrastructure projects, requiring a range of dedicated and structural investments, which implies the involvement of large international financial institutions. Absolute need exists, and the segment of cooperation with international financial institutions, in terms of infrastructure development, is very important and must be constant in order to accommodate all the conditions for the development of a modern society as a whole.

\section{REFERENCES}

[1] Acin Dj. Pigmalion, International Economic Relations, Novi Sad (2007), page 3-8.

[2] Hadzić M., Barać S., Stakić B., Ivaniš M., Organization of the Banking, University Singidunum, Belgrade (2008), pages 14-28.

[3] Kapor P., International Business Finance, Megatrend University, Belgrade, (2005), page 12-16.

[4] Kastratović M., International Finance Management, Faculty of International Management. Belgrade (2000), page 23-28.

[5] Knežević et al., "Analiza finansijskih izveštaja" - second edited and revised edition, University Singidunum, Belgrade, 2017, page 259.

[6] Koen P., Jasen, Introduction to the Logic and Scientific Method, Belgrade, (2004), page 8-11.

[7] Kovač O., International Finance, Faculty of Economics in Belgrade, Belgrade, (2003), page 15-27.

[8] Milutin Ćirović, "Finansijski menadžment", page 27, Scientific Society of Serbia, Belgrade, 2008

[9] Miljković D., International Finance and Development, Publishing Center of the Faculty of Economics in Belgrade, Belgrade, (2008), page 5

[10] Miljević M., Methodology of scientific work, Faculty of Philosophy, University of Sarajevo, Sarajevo.Pale, Bosnia and Herzegovina, (2007), page6-14.

[11] Petković T., International Economics and Finance, Senior Business School of Vocational Studies, Čačak, Čačak, (2012), page 3.

[12] Popovčić A., International Economics, Department of Textbooks and Faculty of Economics, Finance and Administration-EFA. Belgrade (2009), page 10-11. 
[13] Reinert E., Global economy-How Rich have become rich and why the poor become even poorer, Cigoja press, Belgrade (2006), page 16.

[14] Stakić B., International Financial Institutions, Business Faculty, University Singidunum, Belgrade (2012), page15-50.

[15] Sovtić K., Foreign Trade Economics, Megatrend University, Belgrade, (2009), page 728

[16] Unković M., International Economics, Business Faculty, University Singidunum, Belgrade, (2010), page 50-210.

[17] www.duboko.rs, company history, accessed on 05.05.2018.

[18] A draft of EIA 2007 - Volume I 163-1/07/Duboko, and non-technical* summary, May $24^{\text {th }}$ 2007. MOL, Belgrade-11

[19] www.gsp.rs, Statistics, accessed on 13.08.2018.

[20] EBRD document, draft of the strategy for Serbia, 2018-2024, Belgrade, Serbia, page 7

[21] EBRD document, draft of the strategy for Serbia, 2018-2024, Belgrade, Serbia, page 10

[22] Financial reports IBRD, IADB, AFDB, AIIB

[23] Asian Infrastructure Investment Bank

[24] Guide to finance EBRD

[25] Finance Guidebook: Debt terms, International Finance Institutions and Bilateral loans, page 23, Government of the Republic of Serbia, Office for European Integrations, Belgrade, 2013

[26] Draft of the strategy for Serbia, 2018-2023, Belgrade, Serbia, page 7

[27] http://www.ebrd.com, strategy for Serbia, 2013 report, visited 27.06.2013, pages 6 and 21.

[28] Strategy for Serbia, 2007 report, visited 21.05.2014, page 14.

[29] http://www.ebrd.com, strategy for Serbia, 2016 report, visited 28.08.2016, page 6.

[30] http://www.mcentsr.rs/arhiva, Čačanska bank process recapitalization view 2014, visited 06.08.2018, page 1 .

[31] http://www.halkbank.rs, main data, novelties 2015, visited 11.04.2015, page 2.

[32] http://www.ifi.com, The role of international financial institutions in the reconstruction of the southeastern Europe, V. Bhargava, chapter 20, visited 27.05.2018, page 393-399.

[33] www.ebrd.com, a Guide to the EBRD financing, EBRD Publications, October 2005, visited 07.06.2013, pages 11-21.

\section{Article history:}

- Received 25 January 2019

- Accepted 5 March 2019 